\title{
CERTAIN CONSIDERATIONS REGARDING THE PROTECTION OF A CAPABLE NATURAL PERSON THROUGH GUARDIANSHIP IN THE LIGHT OF NEW ROMANIAN CIVIL CODE
}

\author{
Daniela Cristina Cret $\mathbf{P h D}$ \\ "Vasile Goldis" Western University of Arad \\ E-mail: danielacret@yahoo.com \\ Cosmina Flavia Bobar ${ }^{1,2}$ \\ "Vasile Goldis" Western University of Arad \\ ${ }^{2}$ „Lucian Blaga” University of Sibiu, Faculty of Law, PhD Candidate \\ E-mail: thetudor2010@yahoo.com
}

(Received January 2016; Accepted February 2016)

\begin{abstract}
One of the measures employed to protect an individual is guardianship. Legal norms treat guardianship aimed at protecting a person with full capacity of exercise in certain special situations in a different way than they do guardianship for minors or persons placed under interdiction. While guardianship for capable persons is governed by the rules of mandate, guardianship for minors and persons placed under judicial interdiction are subject to rules applicable to custody for minors (art. 171 of the New Civil Code). As follows, we shall analyse the legal provisions established by the New Civil Code in the case of guardianship for capable persons, emphasising novelty elements as compared to the previous regulation.
\end{abstract}

\section{Introduction}

The protective measures for major natural persons are, within the meaning of art. 106 para. (2) of the Civil Code, placement under judicial interdiction and guardianship.

In the absence of adequate protective measures for individuals who are unable to care for their own person and assets, and who, at the same time, do not qualify for being placed under judicial interdiction, as they are endowed with discernment, even temporarily, the institution of guardianship is employed.

Guardianship constitutes the temporary and subsidiary means of protection for capable individuals who, being under certain special circumstances, foreseen by law, cannot pursue their own interests [1].

This protective measure is addressed [2] by Chapter IV (art. 178-186) of Title III entitled "Protection of individuals" in Book I of the New Civil Code, but it is also referred in certain articles of Chapter I of the same title, as well as in some provisions of the current Code of Civil Procedure, e.g. art. 58 on special guardianship. 
Cret D.C, Bobar C.F. (2016)

Certain considerations regarding the protection of a capable natural person through guardianship in the light of New Romanian Civil Code

Historically, it can be noted that the institution of guardianship dates back to Roman law. During this period, the Law of the Twelve Tables covered the guardianship of the mentally incapable (in this Act the mentally incapable were designated by the word furiosus, i.e. incurably insane), the guardianship of prodigal persons (prodigi) and the guardianship of minors (Lex Plaetoria, voted in 92-191 $\mathrm{BC}$, considering the insufficient experience of young people under the age of 25 , decided to fine those who would abuse such inexperience) [3].

The guardianship of the mentally incapable was exercised by their closest heirs presumptive. The guardian in this case had the task of managing the property of and person of the mentally incapable, for the purpose of recovery.

The prodigal person (which was treated as a mentally incapable person) was thus considered if he wasted his property legally inherited from ancestors. Subsequently, the category of prodigality was expanded [4], the prodigal person being thus protected against any act of squandering on his part.

Cases where guardianship is established for capable persons are covered by art. 178 of the Civil Code. According to this legal text, in addition to the cases provided by law, the guardianship court may establish guardianship:

a) if, due to old age, illness or physical impairment [5], a person, although capable, is unable to personally manage their property or to defend their interests under appropriate circumstances and if, for good reasons, they are unable to appoint a representative or an administrator. In literature, this form of guardianship is called guardianship for people with disabilities [6]. In this case the competent court shall be that in whose jurisdiction the represented person resides;

b) guardianship for urgent cases is established when, due to illness or other reasons, a person, although capable, cannot, either personally or through a representative, adopt the necessary measures in cases whose resolution cannot be postponed [7]. In this case competence pertains either to the court in whose jurisdiction the represented person resides, or to the court of the place where urgent measures must be taken;

c) another case of establishing guardianship is provided for the situation where a person is bound to be away from home for a long time, and has not appointed a representative or general administrator. This is guardianship on behalf of people who are away from home. In this situation, competence will pertain to the court of the last residence of the person who is away from home in the country;

d) if a person has disappeared without any information about them, and they did not appoint a representative or general administration; this being the guardianship for a missing person In this case competence will pertain to the court of the last residence of the missing person in the country.

The text of art. 178 of the Civil Code maintains the situations provided by the old now-repealed Family Code, but brings certain novelties on the competent court to 
establish guardianship and the appointment of an administrator for the case stated at letter a). Thus, unlike the previous regulation, which established this protective measure to be the task of the guardianship authority, the current Civil Code regulates the competence of the guardianship court in the matter. With regard to the impossibility of the capable party to personally manage their property or protect their interests, due to old age, illness or physical impairment, and to appoint a representative, the current regulation has added the impossibility of appointing an "administrator" in order to correlate the text of art. 178 let. a) with the provisions of art. 792 of the Civil Code regarding the possibility that the party may appoint an administrator to manage property [8].

Guardianship for capable persons is also regulated in the current Code of Civil Procedure. Cases in which a guardian may be appointed under this regulation are:

- the situation in which an entity referred to in art. 56 para. (2) of the Code of Civil Procedure (i.e. associations, companies and other entities without legal personality s.n.), constituted according to law, called upon to be judged, does not have a representative [9]. The special court-appointed guardian has all the rights and obligations provided by law for a legal representative. In the terms of art. 58 of the Code of Civil Procedure, the legal person or entity referred to in this legal text can only have passive legal standing;

- another case in which a special guardian can be appointed by the court concerns heirs [art. 155 para. (1) pt. 15]. In this sense, until their intervention in the trial, they will be summoned at his residence;

- likewise, on the approval of summoning by publication [10], the court will appoint a guardian among bar lawyers, who will be summoned to the trial to represent the interests of the defendant [art. 167 par. (3) of the Code of Civil Procedure]

- in the situation of a joinder of parties, the court may provide for representation by proxy, and if the parties do not choose a representative or do not agree on his person, the judge will appoint a special guardian by ruling, according to art. 58 para. (3) of the Code of Civil Procedure, who will ensure the representation of plaintiffs or defendants and to whom the proceedings will be communicated [11].

The appointment of a special guardian by the court of guardianship is also stated in special laws. The following stand out among these cases: notarial succession guardianship [12]. It is governed in full by art. 101-118 of Law no. 36/1995 on notaries public and notarial activity [ex-art. 72 and ex-art. 15 para. (1) of Decree no. 31/1954], as well as by art. 150 par. (3) and art. 1117 para. (3) of the Civil Code. Under art. 150 par. (3) Civil Code. In the first case, for good reasons, as part of succession proceedings, the notary public, on his own initiative or at the request of any interested party, may appoint a provisional special guardian, who will be validated or, where appropriate, replaced by the guardianship court. Transiently, 
Cret D.C, Bobar C.F. (2016)

Certain considerations regarding the protection of a capable natural person through guardianship in the light of New Romanian Civil Code

art. 229 para. $\left(3^{2}\right)$ of the Law Implementing the Civil Code provides that, until the organization of the guardianship court, the appointment of a special curator as part of succession proceedings is performed by the guardianship authority, at the request of the notary public; this case does not require validation or confirmation by the court. In the second situation, the special guardianship is established by notaries where there is no guardian for the succession, and the preservation of succession assets incurs certain expenses. The special guardian appointed by the notary to administer property has the obligation to return the property and to account to the notary on preservation expenses or management of such property upon completion of the succession proceedings or whenever the notary deems necessary.

\section{Establishing procedure, contents and effects of guardianship}

All of the means to protect individuals provided by the Civil Code are the competence of the guardianship and family court. Guardianship is established, like we shown before, by either the guardianship court at the residence of the represented person, at the place where urgent measures must be taken, or at the last residence of the person away from home or missing in the country (art. $179 \mathrm{C}$. civ.).

Guardianship is established either on request or ex officio.

In this context the guardian is the person appointed by the court, under the provisions of the Civil Code or the Code of Civil Procedure, to represent another person temporarily, to manage their property and to protect their interests [13].

In this respect, art. 180 par. (1) of the New Civil Code provides that guardianship can be entrusted to any natural person with full legal capacity and who is able to fulfil this task.

Guardianship may be instituted at the request of the person to be represented, their spouse, relatives, or those referred to in art. 111 of the Civil Code (i.e. close persons, the administrator or the occupants of the house in which the person to be put under guardianship lives; the Civil Service [14], upon registration of a person's death, or notary public, when opening succession proceedings; the courts; local government bodies; care institutions, and any other persons), among them being the person to be represented. Moreover, supplementing these provisions, art. 180 para. (2) of the new Civil Code provides that, where the interested party has designated a person to be appointed guardian, by unilateral act or mandate contract, concluded in authentic form, that person shall be appointed with priority. However, it can be noted that, according to the same provisions, the appointment of the guardian by the represented person can be removed only for good reasons.

In para. (2) art. 182 provides that "guardianship cannot be instituted without the consent of the represented person, apart from cases where consent cannot be 
Cret D.C, Bobar C.F. (2016)

Certain considerations regarding the protection of a capable natural person through guardianship in the light of New Romanian Civil Code

given". In principle, as stated in the doctrine [15], "taking the consent of the represented person and the agreement of the appointed guardian is the essence of the procedure of establishing guardianship". Particularly, as regards the guardianship of the capable person, taking the consent of the person to be placed under guardianship is a prerequisite for setting up these measures. On the contrary, in the absence of consent, the guardianship court cannot impose the guardianship. Moreover, any act committed by the guardian so appointed shall not be enforceable against the represented person [16].

The exception provided in the second sentence of art. 182 para. (2) of the Civil Code refers to the situation where the represented person is missing and there is no information about them.

The guardian is appointed by the guardianship court, with his consent, in a ruling which is communicated in writing and displayed at the seat of the guardianship court, as well as at the city hall of the residence of the represented person (para. 3). In principle, guardianship may be exercised by any individual with full legal capacity and who is able to fulfil this task [art. 180 par. (1)].

When the person concerned has designated a person to be appointed as guardian, through a unilateral act or a mandate contract, both concluded in authentic form, they shall be appointed with priority. The guardian's appointment can be removed only for good reasons, properly applying the provisions of art. 114-120 of the Civil Code.

The content of guardianship for capable persons is given by a few rules, namely: - the rules of mandate apply [art. 183 para. (1) Civil Code]. In this case, the guardianship court may intervene in the mandate contract of the parties and may determine its limits and give instructions to the guardian, instead of the represented person, in all cases where the latter is unable to do so;

- in exercising guardianship, the guardian must take into account the purpose of establishing guardianship [17]. In this sense, the guardian, in exercising his duties, must consider the cause or reason for the need to establish guardianship.

As regards the effects produced by guardianship, art. 178 of the Civil Code establishes that the imposition of guardianship does not affect the legal capacity of the person the guardian represents, so that they may personally conclude the civil legal act or revoke the guardian etc.

\section{Replacement of the guardian and termination of guardianship}

Regarding the replacement of the guardian, it can be noted that the legislator maintained ex-art. 156 of the Family Code, conferring to the guardian the right to request his replacement three years after the appointment, and for good reasons even before the 3-year term (art. 184 of the Civil Code.). 
Cret D.C, Bobar C.F. (2016)

Certain considerations regarding the protection of a capable natural person through guardianship in the light of New Romanian Civil Code

Regarding the termination of guardianship, one should make the difference between the end of a guardian's office and termination of guardianship.

The termination of guardianship occurs when it is lifted due to the extinction of causes which led to its establishment or through the death of the person placed under guardianship. Individuals who may request for guardianship to be lifted are the guardian, the represented person, or those referred to in art. 111 of the Civil Code (i.e. close persons, the administrator or the occupants of the house in which the person to be put under guardianship lives, the Civil Service, upon registration of a person's death, the notary public, on the occasion of opening inheritance proceedings; courts; local government bodies, care institutions, and any other persons)

The end of the guardian's office occurs either when the represented person revokes his authority, even if the causes that imposed guardianship remain, or at the request of the guardian, after the expiry of a period of three years from appointment [18].

We consider as justified the opinion expressed in the doctrine [19], according to which if the authority granted by mandate has the same object and the same scope as that conferred to the guardian, the appointment of a contractual representative will cause guardianship to be lifted or limited.

In this context it is necessary to analyse the guardian's liability. Two aspects must be considered: liability to the capable person for whom guardianship was established, and liability to third parties; in both cases the rules of mandate apply. To the person placed under guardianship, the guardian will be liable for the damages that can arise as a result of failure or improper fulfilment of his obligations, as well as fraud, but also for simple negligence committed in the execution of the mandate. To third parties, he will answer for his excessive [20] acts under extra-contractual liability.

\section{Conclusions}

The protection of individuals through guardianship is now an effective means of protection for capable individuals who, being under certain special circumstances foreseen by law, cannot pursue their interests.

Most of the provisions governing guardianship are found in the Civil Code, but some provisions referring to it are also found sporadically in the Code of Civil Procedure and in special laws.

It should be noted that there are no significant changes from the old regulation, but some novelty elements may however be found. Unlike the previous regulation, in which the establishment of guardianship rested with the guardianship authority, the current Civil Code enshrines competence in guardianship matters to the guardianship court (art. 107 of the Civil Code). 
Cret D.C, Bobar C.F. (2016)

Certain considerations regarding the protection of a capable natural person through guardianship in the light of New Romanian Civil Code

Another change from previous regulations is the supplementation of art. 178 let. a) with the possibility of an "administrator" being appointed by the capable person who, because of old age, illness or physical infirmity, cannot personally manage their property or protect their interests adequately. This addition sought to attain a correlation to civil norms in property matters, norms which confer the possibility of appointing an administrator to manage property (art. 792 of the Civil Code).

\section{Notes}

[1] See I. Imbrescu, Tratat de dreptul familiei, Editura Lumina Lex, Bucuresti, 2010, p. 440; A. Bacaci, V.- C. Dumitrache, C. Hageanu, Dreptul familiei, editia a 4-a, Editura All Beck, Bucuresti, 2005, p. 350.

[2] In the old regulation, repealed by the enactment of the Civil Code, the guardianship of a major person was found in the provisions of the Family Code, Title III, art. 132, 133, 146; in Decree 31/1954, art. 15, 16; Decree 32/1954, for the application of the Family Code and Decree on individuals and legal entities, art. 14, 34 and 37; art. 44 para. (1) and (2) Code of Civil Procedure (introduced by Government Emergency Ordinance no. 138/2000); art. 114 para. (4) and (5) Code of Civil Procedure (introduced by Law no. 219/2005 for approval of Government Emergency Ordinance no. 138/2000); art. 816 of the Civil Code.

[3] Vl. Hanga, Drept privat roman, Editura Argonaut, Cluj-Napoca, 1996, p. 155.

[4] Ibidem, p. 148-154.

[5] For certain specifications, see C. T. Ungureanu, Desemnarea tutorelui sau a curatorului persoanei fizice in vederea luarii in viitor a unei masuri de protectie, conform Codului civil, in Dreptul nr. 6/2015, p. 49.

[6] O. Ungureanu, Persoana fizica, in O. Ungureanu, C. Jugastru Drept civil. Persoanele, editia a 2-a, revazuta, Editura Hamangiu, 2007, p. 256; E. Lupan, I. Sabau Pop, Tratat de drept civil roman. Vol. II. Persoanele, Editura C. H. Beck, Bucuresti, 2007, p. 236; I. Dogaru, S. Cercel, Drept civil. Persoanele, Editura C. H. Beck, Bucuresti, 2007, p. 230.

[7] In foreign legislation this category of guardianship is found in the form of a mandate for reasons of incapacity in German law, starting on 1 March 2005, of the mandate for incapacity or foreseeable incapacity operating in Quebec province (O. Ungureanu, Persoana fizica, in O. Ungureanu, C. Jugastru, op. cit., p. 256, footnote no. 2) and the mandate for future protection effective in France ( $\mathrm{Ph}$. Malaurie, L. Aynès, Les personnes. La protection des mineurs et des majeurs, $4^{\mathrm{e}}$ èdition, Defrenois, Lextenso èditions, Paris, 2009, p. 307 et seq.; J. Massip, Tutelle des mineurs et protection juridique des majeurs, Defrenois, Lextenso èditions, Paris, 2009, p. 455 et seq.).

[8] See A. Tudorica, in Fl. A. Baias, E. Chelaru, R. Constantinovici, I. Macovei (eds.), Noul Cod civil. Comentariu pe articole, editia a 2-a, Editura C.H. Beck, Bucuresti, 2014, in Biblioteca juridica Legalis.ro (www.legalis.ro), accessed on 12 January 2016.

[9] The appointment of a special guardian is decided by "'the court hearing the trial, among the lawyers specially designated for that purpose by the bar, for each court". According to art. 58 para. (4) of the Code of Civil Procedure, the guardian appointed by the competent court must be remunerated for his work, and the remuneration of the guardian is included in trial costs and would be paid by the losing party (Covasna Tribunal, sentence no. 
Cret D.C, Bobar C.F. (2016)

Certain considerations regarding the protection of a capable natural person through guardianship in the light of New Romanian Civil Code

2412/2013, apud. M. C. Barbu, Noul Cod de procedura civila. Jurisprudenta rezumata, Editura C.H. Beck, Bucuresti, 2014, p. 73).

[10] C.S.J., Civil Section, Dec. no. 223/1994, in Dreptul, no. 12/1994, p. 60-61.

[11] M. Tabarca, Drept procesual civil, vol. I, Teoria generala, Editura Universul Juridic, Bucuresti, 2013, p. 338.

[12] See E. Chelaru, Drept civil. Persoanele, editia a 3-a, Editura C . H. Beck, 2012, p. 166. For the old regulation see O. Ungureanu, Persoana fizica..., in O. Ungureanu, C. Jugastru, op. cit., p. 256; E. Chelaru, op. cit., p. 119.

[13] I. Reghini, Persoana fizica - subiect al raporturilor de drept civil, in I. Reghini, S. Diaconescu, P. Vasilescu, Introducere in dreptul civil, editia a 2-a, revazuta si adaugita, Editura Sfera Juridica, Cluj-Napoca, 2008, p. 132.

[14] According to art. IX of Law no. 60/2012, the term "Civil Service(s)" was replaced by "Local Public Community Service(s) of Personal Records".

[15] See P. Perju, in M.-M. Pivniceru, P. Perju, C. Voicu Codul civil adnotat. Despre legea civila. Despre persoane, Editura Hamangiu, Bucuresti, 2013, p. 257.

[16] See E. Lupan, Drept civil. Persoana fizica, Editura Lumina Lex, Bucuresti, 1999, p. 268.

[17] O. Ungureanu, Persoana fizica, in O. Ungureanu, C. Jugastru, op. cit., p. 257.

[18] Gh. Beleiu, Drept civil roman. Subiectele dreptului civil, editia a IX-a revizuita si adaugita, Editura Universul Juridic, Bucuresti, 2007, p. 387.

[19] E. Lupan, I. Sabau Pop, op. cit., p. 238.

[20] For relations between the representative and third parties, see Fr. Deak, Tratat de drept civil. Contracte speciale, editia a IV-a actualizata de L. Mihai, R. Popescu, vol. II, Editura Universul Juridic, Bucuresti, 2006, p. 242.

\section{Bibliography}

1. Bacaci A., Dumitrache V.- C., Hageanu C., Dreptul familiei, editia a 4-a, Editura All Beck, Bucuresti, 2005

2. Baias Fl. A., Chelaru E., Constantinovici R., Macovei I. (coord.), Noul Cod civil. Comentariu pe articole, editia a 2-a, Editura C. H. Beck, Bucuresti, 2014

3. Barbu M. C., Noul Cod de procedura civila. Jurisprudenta rezumata, Editura C.H. Beck, Bucuresti, 2014

4. Beleiu Gh., Drept civil roman. Subiectele dreptului civil, editia a IX-a revizuita si adaugita, Editura Universul Juridic, Bucuresti, 2007

5. Chelaru E., Drept civil. Persoanele, editia a 3-a, Editura C . H. Beck, 2012

6. Deak Fr., Tratat de drept civil. Contracte speciale, editia a IV-a, actualizata de L. Mihai, R. Popescu, vol. II, Editura Universul Juridic, Bucuresti, 2006

7. Dogaru I., Cercel S., Drept civil. Persoanele, Editura C. H. Beck, Bucuresti, 2007

8. Hanga Vl., Drept privat roman , Editura Argonaut, Cluj-Napoca, 1996

9. Imbrescu I., Tratat de dreptul familiei, Editura Lumina Lex, Bucuresti, 2010 


\section{JOURNAL OF LEGAL STUDIES}

"Vasile Goldiș" Western University of Arad

Cret D.C, Bobar C.F. (2016)

Certain considerations regarding the protection of a capable natural person through guardianship in the light of New Romanian Civil Code

10. Lupan E., Sabau Pop I., Tratat de drept civil roman. Vol. II. Persoanele, Editura C. H. Beck, Bucuresti, 2007

11. Malaurie $\mathrm{Ph}$., Aynès L., Les personnes. La protection des mineurs et des majeurs, $4^{\mathrm{e}}$ èdition, Defrenois, Lextenso èditions, Paris, 2009

12. Massip J., Tutelle des mineurs et protection juridique des majeurs, Defrenois, Lextenso èditions, Paris, 2009

13. Pivniceru M.-M., Perju P., Voicu C., Codul civil adnotat. Despre legea civila. Despre persoane, Editura Hamangiu, Bucuresti, 2013

14. Reghini I., Diaconescu S., Vasilescu P., Introducere in dreptul civil, editia a 2a, revazuta si adaugita, Editura Sfera Juridica, Cluj-Napoca, 2008

15. Tabarca M., Drept procesual civil, vol. I, Teoria generala, Editura Universul Juridic, Bucuresti, 2013

16. Ungureanu C. T., Desemnarea tutorelui sau a curatorului persoanei fizice in vederea luarii in viitor a unei masuri de protectie, conform Codului civil, in Dreptul nr. 6/2015

17. Ungureanu O., Jugastru C., Drept civil. Persoanele, editia a 2-a, revazuta, Editura Hamangiu, 2007. 